\title{
Islamic Values and Principles in the Organization: A Review of Literature
}

\author{
Ahmad Rafiki ${ }^{1} \&$ Kalsom Abdul Wahab ${ }^{1}$ \\ ${ }^{1}$ Faculty of Economics and Muamalat, Islamic Science University of Malaysia, Bandar Baru Nilai, Negeri \\ Sembilan, Malaysia. \\ Correspondence: Ahmad Rafiki, Faculty of Economics and Muamalat, Islamic Science University of Malaysia, \\ Bandar Baru Nilai, Negeri Sembilan, Malaysia. Tel: 62-821-6588-8166. E-mail: hahmadrafiki@gmail.com
}

\author{
Received: February 25, 2014 Accepted: March 27, 2014 Online Published: April 7, 2014 \\ doi:10.5539/ass.v10n9p1 URL: http://dx.doi.org/10.5539/ass.v10n9p1
}

\begin{abstract}
This paper attempts to review the literature on the Islamic values and principles in an organization, then presents the importance of its delineated dimensions. Two main theories of Islamic work ethics and practices are discussed comprehensively based on the Qur'anic verses as the ultimate source in Islamic thinking. The review includes the comparison between certain components' implementations and the views of other religions in several countries. This reveals that each of dimensions are clearly functional in organizations. It suggests that Islamic emphasizes on commercial activities which denied the authors' opinions on its' teaching for not governing the materials aspect or success in business performance. The Islamic religion seeks to deliver the goodness to all mankind according to its rules and principles. The integrated system of the Islamic worldview encompasses all aspects of both worldly and hereafter-including the aspect of business.
\end{abstract}

Keywords: Islamic values, Islamic principles, Islamic work ethics, Islamic practices

\section{Introduction}

Religion is one of the most influential social institutions that is significantly associated with people's attitudes, values and behaviours. It tells specifically the effects to the organization matters include on the managers and employees' approaches and decisions. Spilka et al. (2003) asserted that religion plays an inseparable role in numerous forms of human interactions. As a comprehensive religion, Islam governed all aspect of life as an integrated system that clearly stressed on the importance of its values and practices in order to seek Allah's blessings and mercy (rida). While, in business field, a combination of profit and mashlahah maximization would bring the business into achieving real success.

The researches examine both relationships of religious and work attitudes on the linkage at the individual or firm level (Niles, 1999). However, further works need to examine both relationship with other religion perspectives like in Islam. Table 1. below is the summary of the impact of the religious elements in an organization.

Table 1. The impact of religion elements to the organization

\begin{tabular}{|c|c|c|}
\hline Category & Authors & The Impact \\
\hline $\begin{array}{l}\text { Religion } \\
\text { (Individual } \\
\text { Level) }\end{array}$ & $\begin{array}{l}\text { Emmons and Paloutzian, (2003); Pargament et } \\
\text { al. (2005); Regnerus and Smith (2005); } \\
\text { Krishnakumar and Neck (2002); Tischler et al. } \\
\text { (2002); Kale and Shrivastava (2003); Fleming } \\
\text { (2004); Anderson (2005); Kinjerski \& Skrypnek } \\
\text { (2006); Milliman et al. (2003) }\end{array}$ & $\begin{array}{l}\text { Creativity, honesty and trust, personal } \\
\text { fulfillment, commitment, motivation and job } \\
\text { satisfaction, and organisational commitment. }\end{array}$ \\
\hline $\begin{array}{l}\text { Religion } \\
\text { (Firm Level) }\end{array}$ & $\begin{array}{l}\text { Brotheridge and Lee (2007); Duffy (2006); } \\
\text { Ebaugh et al. (2003); Hilary and Hui (2009); } \\
\text { Longenecker et al. (2004); Mickel and } \\
\text { Dallimore (2009); Vitell (2009); Brown (2003). }\end{array}$ & $\begin{array}{l}\text { Emotional development and spiritual } \\
\text { competence, encouraged holistic ways of } \\
\text { working, developed community at work, } \\
\text { empowered the workforce and human } \\
\text { society, risk aversion and ethics, stress } \\
\text { management and career development. }\end{array}$ \\
\hline
\end{tabular}




\section{Literature Review}

\subsection{Islamic Work Ethics (IWE)}

The implementation of the Islamic ethics or akhlaqul karimah was the first message of Allah given to His Messenger, Prophet Muhammad (PBUH). A Hadith clearly conveyed a message on the importance of akhlaqul karimah in Islam as narrated by Bukhari whereby: "I (Muhammad) have only been sent to complete good manners (Makarim Al- Akhlaq)" (Note 1). Ahmad (2006) has added that Muslims who wish to be granted the pleasure of Allah, may achieve this by applying the core values of ethics.

Islamic work ethics is rooted based on Al-Qur'an and Sunnah which concern with Islamic values, belief and practices (Arslan, 2005) which defined as the set of moral principles that differentiate what is right from what is wrong (Beekun, 1997). It inspires confidence in the workplace, reinforces social business responsibilities (Ali, 2005) and has a work-orientation as a virtue in human life (Rizk, 2008). These are also applied in any business applications and behaviors that every Muslims should observe and engage in as the servants of God (Beekun \& Badawi, 2004) through hard working, commitment, dedication, work creativity, avoidance of wealth accumulation, cooperation and competitiveness at the work place (Yousef, 2001). It is noted that Prophet Muhammed (PBUH) encouraged Muslims to work as much on his/her ability (Ali, 2005). The IWEs' items are summarized in Table 2 as proposed by Ali (1988) and the reference in Al-Qur'an.

Table 2. The Al-Qur'an reference of Islamic work ethics

\begin{tabular}{|c|c|}
\hline Subject & Al-Qur'an Verses \\
\hline $\begin{array}{l}\text { Agreements and } \\
\text { promises }\end{array}$ & Ar-Rad 13:25, Al-Qasas 28:28, Yunus 10:71 \\
\hline Consideration for others & An-Nisaa’ 4:36, Al-Mumtahina 60: 9. \\
\hline Consultation & Ash-Shura 42:38, Taha 20:103, Al-Kahf 18:22 \\
\hline Continuous improvement & Al-Araf 7:42. \\
\hline Cooperation. & Al-Hujraat 49:9, Maryam 19:96. \\
\hline Equality and unity & Al-Isra’ 17:35. \\
\hline Fairness in dealings & Al-Anaam 6:152, Al-Mumtahina 60:8, An-Najm 53:32, Al-Maida 5:8. \\
\hline Fairness in wages. & Al-Imran 3:57, Saba’ 34:37. \\
\hline Hard work. & Al-Baqara 2:62; 82, Al-Anaam 6:135 \\
\hline Helping others & As-Saff 61:14, An-Nahl 16:97, Yunus 10:41 \\
\hline Honesty and justice. & Al-Baqara 2:177, Az-Zumar 39:2; 3 \\
\hline Humble. & Hud 11:23 \\
\hline Patience. & Hud 11:11 \\
\hline Righteous/Intention & $\begin{array}{l}\text { Al-Baqara 2:25; 225, Al-Baqara 2:62, At-Taubah 9:105, As-Saff 61:8, Al-Qasas } \\
28: 19\end{array}$ \\
\hline Social order. & Al-Imran 3:110, Al-Baqara 2:273 \\
\hline Truth. & Al-Anfal 8:27, Yunus 10:61, An-Nur 24:8 \\
\hline
\end{tabular}

Source: Adapted from Ali (1987)

Many studies conducted by the following authors, i.e. Al Habtoor (2001), Yousef (2001), Ali (2005), Ali and Al-Owaihan (2008) have concluded that the IWE contributes to higher performance and brings widespread prosperity and societal welfare. They also agree on the adoption of the IWE in managerial, business operations and economic activities. One of the popular measurement scales of Islamic work ethics was constructed by Ali (1988). He ran a test, among 150 Arab students in major universities in the United States. This scale has been used by researchers in both organizational and management contexts (Yousef, 2001; Rahman et al., 2006; Ali \& Al-Kazemi, 2007; Khalil \& Abu-Saad, 2009; Kumar \& Rose, 2010). They conducted the studies in respective countries, such as the United Arab Emirate, Malaysia and Kuwait and concluded that the IWE is directly affected and that it has a strong relationship with organizational change, committment, and work satisfaction. However, in 
his in-depth interviews of 32 business people in Turkish SMEs, Uygur (2009) establishes that the IWE is not a significant factor for their attitudes.

Comparatively, the studies on work ethics of the conventional version have been conducted by Koh and Boo (2001) and Lambert and Hogan (2009) for the cases in Singapore and United States respectively, whereby work ethics has been indicated to have the largest impact on work satisfaction. However, Elkins (2007) argues that there is a weak correlation between work ethics and work satisfaction in relation to the Japanese manufacturing company. Regardless of the positive or negative findings in terms of studies on work ethics and success either in the conventional concept or the Islamic concept, Muslims are obliged to adopt the IWE as instructed in Al-Qur'an and Hadith.

\subsection{Islamic Practices and Firm Performance}

Islam is a universal religion that is meant for all human beings on earth and could be implemented at any time at all, while the word'comprehensive' relates to the complete and perfect teachings (syumul). This is stated in Al-Qur'an. Al-An'am 6:38. As stated earlier by Rivai et al. (2012) Islam has three pillars of tawheed, shariah and akhlaq. Ahmad (2006) briefly explains each of these three items; Tawheed is a basic belief of Muslim that means the establishment of the Unity of Allah; Shariah can be described as Muslims' code of conduct based on Al-Qur'an and Hadith; Akhlaq refers to the practice of virtue, morality and manners. A Muslim entreprenuer is required to have Tawheed as a total conviction to Allah as the Only Sustainer and the acceptance of His divine assistance that provides the Muslims with a source of security. The Tawheed paradigm can address the issue of integration in organisations and it provides an intellectual understanding of the unity of the creation and existence (Ahmad, 2006). This is asserted in the Al-Qur'an. Al-ikhlas 112:1 and Al-baqara 2:186.

Islam integrates religious practices of business activities with personal worship. Combining these practices in good intention is called an ibadah. All of the practices have been cited in Al-Qur'an and Hadith or based on the guidelines encompassing various shariah rules, muamalat and ethical values (akhlaq Islamiyyah) such as Islamic finance, halal certification, Islamic motivation in work, Islamic education, Islamic business training, Islamic networking (jemaah), payment of zakat, honesty, good intention (niyyah), dedication, creativity, optimism, committment, tenacity and hard working.

The Islamic practices are categorized into actions of fardhu a'in (individual's compulsory obligation) and kifayah (individual's optional obligation). Fardhu a'in refers to practices that are mandatory to the Muslims and ignoring them is sinful and therefore, punishable. These include the Islamic pillars of belief in One Creator-God as the Sustainer and Prophet Muhammad (PBUH) as the messenger of God, praying or (solat) five times a day, fasting during the month of Ramadhan, paying zakat, perform Hajj to Mecca, and other ibadah of obeying Allah by doing everything that He ordains and avoiding everything He forbids. Meanwhile, fardhu kifayah refers to that the condition whereby if any Muslim has done the practices, other Muslims are not required to do so. For example, attending Islamic business training to learn financial or marketing strategies, where Muslims are not obliged to learn such knowledge (although in other perspectives, every Muslim has the responsibility to acquire knowledge).

The involvement of Islam in business and management has been explained in detail. All of these influences of Islamic practices on an organisation aim at achieving al-falah (success in this world and the hereafter). This, therefore, negates the notion that Islam does not emphasize commercial activities or that it is unrelated to any of the organisational behaviors. Some studies on Islamic management practices in various countries are depicted in Table 3 .

Table 3. Islamic management practice

\begin{tabular}{|c|c|}
\hline Islamic Management Practices & Authors \\
\hline Ethics \& social responsibility in management & $\begin{array}{l}\text { Beekun (1997); Ahmad (1996); Hanafi } \\
\text { and Sultan (1995); Gambling and Karim } \\
\text { (1991); Al Habshi and Ghazali (1994) }\end{array}$ \\
\hline Organisational behavior & Shareef (1995); Al-Alwani (1995) \\
\hline Leadership in organisations & $\begin{array}{l}\text { Beekun and Badawi (2004); Ezzati } \\
\text { (1982); Shirazi (1980) }\end{array}$ \\
\hline
\end{tabular}

Motivation in organisations

Abdel Rahman (1995); Sharfuddin (1995); Ahmad (1995). 
Human resource management

Organisational communication

Quality management

Mutual consultation, advice, conflict resolution, work satisfaction, merit system in recruitment and promotion, mutual trust (management and employees) and the use of control and authority

Self-management, managing people, managing business transactions, and managing time

Planning, collectivism, leading, competition and conflicts

Strategic Management
Ali (2005); Aghazadeh (2003); Tayeb (1997); Ramzan (1992); Beekun (1997).

Siddiqui (1988)

Sadeq and Israil (1996)

Ahmad (2006); Beekun (2006); Ali (2005); Sharfuddin (1987).

Moursi (1995)

Jabnoun (1994); Al-Buraey (1990); Abu Sin (1981)

Khalifa (2001)

In regard to the implementation of Islamic practices, it prescribes an extensive set of ways and regulations based on the four servitude principles namely the devotion to God, a committed heart, truthful words, and rightful deeds (Angha, 2002). It is also a framework that shapes the behavior of one-fifth of the world's total population including those who are engaged in business and other facets of life across 50 countries (Jamaluddin, 2003). The reference from Al-Qur'an as the guidance on the adoption of Islamic practices is summarized in Table 4.

Table 4. The Islamic practices' sources from Al-Qur'an

\begin{tabular}{|c|c|}
\hline Reference & Subject \\
\hline Al Quran. An-Nur 24:37, Fatir 35:29 & $\begin{array}{l}\text { The importance rememberance of Allah, do prayers while } \\
\text { in trade and sales engagement }\end{array}$ \\
\hline Al Quran. Ad-Dzariyat 51:57 & Obligation of mankind for an ibadat \\
\hline Al Quran. Al-Qasas 28:77 & $\begin{array}{l}\text { Seeking of wealth, not to mischief and the aim of the } \\
\text { Hereafter. }\end{array}$ \\
\hline $\begin{array}{l}\text { Al Quran. Ghafir 40:58; Al-Baqarah 2:30-33; } \\
\text { Al-Mujadila 58:11; Luqman 31:20 }\end{array}$ & The importance of training, learning and development \\
\hline The Quran, An-Nisaa' 4:58-59 & $\begin{array}{l}\text { Implementation of human resources in the way of God with } \\
\text { trust and responsibility }\end{array}$ \\
\hline Al Quran. Al-Baqarah 2:286 & Doing job based on capacity and competency \\
\hline AlQuran.Al-Ahqaf 46:19 & $\begin{array}{l}\text { Grading the em[ployees work based on quality and } \\
\text { quantity of their work }\end{array}$ \\
\hline Al Quran. Al-Araf 7:85 & Understanding the contract and meet the conditions \\
\hline Al Quran. Al-Kahf 18:87-88 & Economic/Business Performance \\
\hline Al Quran. Al-Baqarah 2:42, At-Taubah 9:16 & $\begin{array}{l}\text { Accurate information and prohibited false assertions, } \\
\text { unfounded accusation and false testimonies }\end{array}$ \\
\hline Al Quran. Al-Furqan 25: 67 & Balance between those (extremes) \\
\hline AlQuran.Al-Qasas 28:26-28 & Mutual consultation and consent \\
\hline
\end{tabular}

Source: Adapted from Ali (1988), Ahmad (2006) and Rivai et al. (2012)

In adopting Islamic practices, Muslims are driven by a kind of faith which is otherwise known as iman. Islam considers iman as the basic motivating factor for believers which determines their conscience. All business decisions must be guided by iman, which practically means abiding by the shariah law, engaging in the things that are permitted (halal), avoiding those thatare forbidden (haram) (Alawneh, 1998). Business decision makers are free to make choices, but religious principles provide a framework for the appropriate exercise of that choice (Ali \& Gibbs, 1998). 


\section{Conclusion}

The Islamic values and ethics are based on the statements in Al-Qur'an and Hadith that may be cited in other religious thoughts but the tawheedic view may differentiate between Muslims andother adherents. Those elements are seen to be able to be adopted in analyzing business performance in the organizations through their beneficial concepts and functions; however, the empirical studies which argue on, and compare between the Islamic and the conventional methods used by many researchers for years, should be conducted. The shariah-compliance concept should be superior to other concepts. Muslims are obliged to implement all elements as an act of an ibadah, aiming to get the rida'or blessings from Allah SWT in their life endeavours.

\section{References}

Abdel Rahman, A. R. A. (1995). An Islamic perspective on organisational motivation. American. Journal of Islamic Social Sciences, 12(2), 185-203.

Abu Sin, A. E. (1981). Islamic Administration. Dubai: The Contemporary Press.

Aghazadeh, S. (2003). The future of human resource management. Work Study, 52(4), 201-207. http://dx.doi.org/10.1108/00438020310479045

Ahmad, F. (1995). Work motivation in organisational setting: An Islamic perspective. In F. R. Faridi (Ed.), Islamic Principles of Business Organisation and Management. New Delhi: Qazi Publishers and Distributors.

Ahmad, K. (2006). Management from the Islamic Perspective. Kuala Lumpur: International Islamic University Malaysia, Reasearch Center.

Ahmad, M. (1996). Business Ethics in Islam. Herndon, VA: IIIT.

Al Habshi, S. O., \& Ghazali, A. (Eds.). (1994). Islamic Values and Management. Kuala Lumpur: IKIM.

Al Habtoor, K. A. (2001). An Alternative to Globalized Economy - Islamic Economics. Thinking Clearly: A Collection of Essays and Research on Regional and Global Issues Affecting the Arab World. No. 42.

Al-Alwani, T. J. (1995). Towards Islamization of organisational behavior. In F. R. Faridi (Ed.), Islamic Principles of Business Organisation and Management. New Delhi: Qazi Publishers and Distributors.

Alawneh, S. F. (1998). Human motivation: An Islamic perspective. American Journal of Islamic Social Sciences, 15(4), 19-39.

Al-Buraey, M. A. (1990). Management and Administration in Islam. Saudi Arabia: Al-Dharan.

Ali, A. (1988). Scaling an Islamic Work Ethic. The Journal of Social Psychology, 128(5), 575-583. http://dx.doi.org/10.1080/00224545.1988.9922911

Ali, A. J. (2005). Islamic perspectives on management and organisation. Northampton, MA: Edward Elgar.

Ali, A. J., \& Al-Owaihan, A. (2008). Islamic work ethic: A critical review. Cross Cultural Management Development, 14(6), 5-19. http://dx.doi.org/10.1108/13527600810848791

Ali, A. J., \& Gibbs, M. (1998). Foundations of business ethics in contemporary religious thought: The ten commandment perspective. International Journal of Social Economics, 25, 1552-1564. http://dx.doi.org/10.1108/03068299810214089

Ali, A., \& Al-Kazemi, A. (2007). Islamic work ethic in Kuwait. Journal of Management Development, 14(2), 366-375.

Anderson, K. P. (2005). A correlational analysis of servant leadership and job satisfaction in a religious educational organisation. Dissertation Abstract International, 66(1), 239.

Angha, N. (2002). Theory "I" the unlimited vision ... of leadership. Riverside, CA: M. T. O. Publications.

Arslan, M. (2001). The Work Ethic Values of Protestant British, Catholic Irish and Muslim Turkish Managers. Journal of Business Ethics, 31, 321-339. http://dx.doi.org/10.1023/A:1010787528465

Arslan, M. (2005). Is ve Meslek Ahlaki (Business and Professional Ethics). Ankara: Siyasal yayinevi.

Beekun, R. (1997). Islamic Business Ethics. Herndon, VA: The International Institute of Islamic Thought.

Beekun, R. E. (2006). Strategic Planning and Implementation for Islamic Organisations. Herndon, VA: International Institute of Islamic Thought.

Beekun, R. I., \& Badawi, J. (2004). Leadership: An Islamic perspective (2nd ed.). Beltsville, MD: Amana Publication.

Brotheridge, C. M., \& Lee, R. T. (2007). Hands to work, hearts to God: Religiosity and organizational behavior. Journal of Management, Spirituality and Religion, 4(3), 287-309. 
http://dx.doi.org/10.1080/14766080709518666

Brown, R. B. (2003). Organisational spirituality: The skeptic's version. Organisation, 10(2), 393-393.

Duffy, R. D. (2006). Spirituality, religion, and career development: Current status and future directions. Career Development Quarterly, 55(1), 52-63. http://dx.doi.org/10.1002/j.2161-0045.2006.tb00004.x

Ebaugh, H. R., Pipes, P. F., \& Chafetz, J. S. (2003). Where's the religion? Distinguishing faith-based from secular social service agencies. Journal for the Scientific Study of Religion, 42(3), 411-426. http://dx.doi.org/10.1111/1468-5906.00191

Elkins, S. L. (2007). Job satisfaction and work ethic among workers in a Japanese manufacturing company located in the United States. PhD Thesis, The University of Tennessee.

Emmons, R. A., \& Paloutzian, R. F. (2003). The psychology of religion. Annual Review of Psychology, 54(1), 377-402. http://dx.doi.org/10.1146/annurev.psych.54.101601.145024

Ezzati, A. F. (1982). The concept of leadership in Islam. Al-Nahdah, 2(2), 24-29.

Fleming, K. Y. (2004). Soulful leadership: Leadership characteristics of spiritual leaders contributing to increased meaning in life and work. Dissertation Abstracts International, 65(1), 211 A.

Gambling, T., \& Karim, R. (1991). Business and Accounting Ethics in Islam. London: Mansell.

Hanafi, A. A., \& Sultan, H. (1995). Business ethics: an Islamic perspective. In F. R. Faridi (Ed.), Islamic Principles of Business Organisation and Management. New Delhi: Qazi Publishers and Distributors.

Hilary, G., \& Hui, K. W. (2009). Does religion matter in corporate decision making in America? Journal of Financial Economics, 93(3), 455-473. http://dx.doi.org/10.1016/j.jfineco.2008.10.001

Jabnoun, N. (1994). Islam and Management. Institut Kajian Dasar, Kuala Lumpur.

Jamaluddin, S. (2003). Understanding the framework of business in Islam in an era of globalization: A review. Business Ethics: A European Review, 12(1), 23-32. http://dx.doi.org/10.1111/1467-8608.00302

Kale, S. H., \& Shrivastava, S. (2003). The enneagram system for enhancing workplace spirituality. Journal of Management Development, 22(4), 308-328. http://dx.doi.org/10.1108/02621710310467596

Khalifa, A. S. (2001). Towards and Islamic Foundation of Strategic Business Management. Kuala Lumpur: International Islamic University Malaysia.

Khalil, M., \& Abu-Saad, I. (2009). Islamic work ethic among Arab college students in Israel. Cross Cultural Management: An International Journal, 16(4), 333-346. http://dx.doi.org/10.1108/13527600911000320

Khraim, H. (2010). Measuring Religiosity in Consumer Research From an Islamic Perspective. Journal of Economic \& Administrative Sciences, 26(1), 52-78. http://dx.doi.org/10.1108/10264116201000003

Kinjerski, V. M., \& Skrypnek, B. J. (2006). Creating organisational conditions that foster employee spirit at work. Leadership and Organisation Development Journal, 27(4), 280-295. http://dx.doi.org/10.1108/01437730610666037

Koh, H. C., \& Boo, E. H. (2001). The link between organizational ethics and Job satisfaction: A study of managers in Singapore. Journal of Business Ethics, 29, 309-324. http://dx.doi.org/10.1023/A:1010741519818

Krishnakumar, S., \& Neck, C. P. (2002). The what, why and how of spirituality in the workplace. Journal of Managerial Psychology, 17(3), 153-164. http://dx.doi.org/10.1108/02683940210423060

Kumar, N., \& Rose, R. C. (2010). Examining the link between Islamic work ethic and innovation capability. Journal of Management Development, 29(1), 79-93. http://dx.doi.org/10.1108/02621711011009081

Lambert, E., \& Hogan, N. (2009). The importance of job satisfaction and organisational commitment in shaping turnover intent. Criminal Justice Review, 34(1), 96-118. http://dx.doi.org/10.1177/0734016808324230

Longenecker, J. G., McKinney, J. A., \& Moore, C. W. (2004). Religious intensity, Evangelical Christianity, and business ethics: An empirical study. Journal of Business Ethics, 55(4), 373-386. http://dx.doi.org/10.1007/s10551-004-0990-2

Mickel, A. E., \& Dallimore, E. J. (2009). Life-quality decisions: Tension-management strategies used by individuals when making tradeoff. Human Relations, 62(5), 627-668. http://dx.doi.org/10.1177/0018726709103453

Milliman, J., Czaplewski, A. J., \& Ferguson, J. (2003). Workplace spirituality and employee work attitudes: An exploratory empirical assessment. Journal of Organisational Change Management, 16, 426-447. http://dx.doi.org/10.1108/09534810310484172

Moursi, M. A. (1995). Some principles of management in Islam. In F. R. Faridi (Ed.), Islamic Principles of 
Business Organisation and Management. New Delhi: Qazi Publishers and Distributors.

Niles, F. S. (1999). Toward a Cross-cultural Understanding of Work-related Beliefs. Human Relations, 52, 855-867. http://dx.doi.org/10.1177/001872679905200701

Pargament, K. I., Magyar-Russell, G. M., \& Murray-Swank, N. A. (2005). The sacred and the search for significance: Religion as a unique process. Journal of Social Issues, 61(4), 665-687. http://dx.doi.org/10.1111/j.1540-4560.2005.00426.x

Preston, R. (1987). The Future of Christian Ethics. London: SCM.

Rahman, N. M., Muhamad, N., \& Othman, A. S. (2006). The relationship between Islamic work ethics and organisational commitment: a case analysis. Malaysian Management Review, 41(1), 79-89.

Ramzan, A. K. (1992). An Islamic framework for employer-employee relationships. The American Journal of Islamic Social Sciences, 9(2), 202-218.

Regnerus, M. D., \& Smith, C. (2005). Selection effects in studies of religious influence. Review of Religious Research, 47(1), 23-50. http://dx.doi.org/10.2307/4148279

Rivai, V., Nuruddin, A., \& Arfa, F. A. (2012). Islamic Business and Economic Ethics. Jakarta: Bumi Aksara.

Rizk, R. R. (2008). Back to basics: an Islamic perspective on business and work ethics. Social Responsibility Journal, 1(2), 246-254. http://dx.doi.org/10.1108/17471110810856992

Sadeq, A. H. M., \& Israil, A. K. B. M. (Eds.). (1996). Quality Management: Islamic Perspectives. Kuala Lumpur: Leed Publications.

Shareef, G. A. (1995). Islamic principles of organisationl behavior: A conceptual outline. In F. R. Faridi (Ed.), Islamic Principles of Business Organisation and Management. New Delhi: Qazi Publishers and Distributors.

Sharfuddin, I. O. (1995). Motivation the cornerstone of human performance: An Islamic and comparative perspective. In F. R. Faridi (Ed.), Islamic Principles of Business Organisation and Management. New Delhi: Qazi Publishers and Distributors.

Sharfuddin, I. O. M. (1987). Towards an Islamic administrative theory. The American Journal of Islamic Social Sciences, 4(2), 229-244.

Shirazi, A. N. M. (1980). Management and leadership in the life of the prophet. Al-Tawhid, 5(2), 157-165.

Siddiqui, M. A. (1988). Interpersonal communication: modelling interpersonal relationship. An Islamic Perspective, 5(2), 239-246.

Tayeb, M. (1997). Islamic revival in Asia and human resource management. Employee Relation, 19(4), 352-364. http://dx.doi.org/10.1108/01425459710170086

Tischler, L., Biberman, J., \& McKeage, R. (2002). Linking emotional intelligence, spirituality and workplace performance: Definitions, models and ideas for research. Journal of Managerial Psychology, 17(3), 203-218. http://dx.doi.org/10.1108/02683940210423114

Uygur, S. (2009). The Islamic work ethic and the emergence of Turkish SME owner-managers. Journal of Business Ethics, 88(1), 211-225. http://dx.doi.org/10.1007/s10551-009-0107-z

Vitell, S. J. (2009). The role of religiosity in business and consumer ethics: A review of the literature. Journal of Business Ethics, 90(2), 155-167. http://dx.doi.org/10.1007/s10551-010-0382-8

Yousef, D. A. (2001). Islamic work ethics: A moderator between organisational commitment and job satisfaction in across-cultural context. Personnel Review, 30(2), 152-169. http://dx.doi.org/10.1108/00483480110380325

\section{Note}

Note 1. Hadith Al-Bukhari. Sahih Bukhari. Al-Jami'ul Musnad Al-Sahih Al-Mukhtasar min Umoorir Rasool Sallallahu Alaihi Wasallam wa Sunanihi wa Ayyamihi, Juz 2:\#4221. p. 670.

\section{Copyrights}

Copyright for this article is retained by the author(s), with first publication rights granted to the journal.

This is an open-access article distributed under the terms and conditions of the Creative Commons Attribution license (http://creativecommons.org/licenses/by/3.0/). 